\title{
Bicyclo[2.2.2] octane analogues of patchouli alcohol by Sakurai reaction and Nagata cyclization. Synthesis and olfactory properties of novel isopropyl derivatives ${ }^{\dagger}$
}

\author{
Angela La Bella,, , b Ilaria Popolla, ${ }^{\text {a, b }}$ Marco Felici, ${ }^{\text {a, b }}$ Francesca Leonelli, , b \\ Francesca Ceccacci, ${ }^{\text {a, b }}$ Luigi Filocamo, ${ }^{c}$ Luisa Maria Migneco, ${ }^{\text {a, b }}$ \\ and Rinaldo Marini Bettolo ${ }^{a, b^{*}}$ \\ ${ }^{a}$ Istituto di Chimica Biomolecolare del CNR, Sezione di Roma, ${ }^{b}$ Dipartimento di Chimica, \\ 'Dipartimento di Scienze Biochimiche "A. Rossi Fanelli" \\ Università degli Studi di Roma "La Sapienza”, P.le Aldo Moro 5, I-00185 Roma, Italy \\ E-mail: rinaldo.marinibettolo@uniroma1.it
}

Dedicated to Prof. Csaba Szántay on his $80^{\text {th }}$ birthday

\begin{abstract}
The synthesis of bicyclo[2.2.2] octane patchouli alcohol analogues by the Sakurai conjugate addition and Nagata cyclization is described. By this approach, complementary to those so far adopted and based on the Diels-Alder addition, known analogues 2, 3 and $\mathbf{2 0}$ and new analogues 8-11, with 1-isopropylbicyclo[2.2.2] octane structure, could be obtained. The olfactory properties of $\mathbf{8}$ and $\mathbf{1 0}$ were also evaluated.
\end{abstract}

Keywords: 1-isopropylbicyclo[2.2.2] octane derivatives, synthesis, Sakurai allylation, Nagata cyclization, patchouli alcohol analogues, olfactory properties

\section{Introduction}

The olfactory properties of patchouli alcohol 1, a sesquiterpenoid largely available from natural sources, are well known. Since total synthesis ${ }^{2}$ has proven uneconomical, a systematic search for synthetic analogues with simpler structures I ( $\mathrm{R}=\mathrm{H}$, alkyl, alkenyl) and II ( $\mathrm{R}=\mathrm{H}$, alkyl, alkenyl) has been carried out by Spreitzer $^{3}$ and Weyerstahl. ${ }^{4}$

\footnotetext{
${ }^{\dagger}$ The work described in this paper constitutes part of the Ph.D. Thesis of A.L.B. ${ }^{1}$
} 


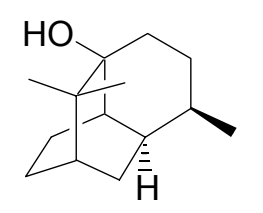

1
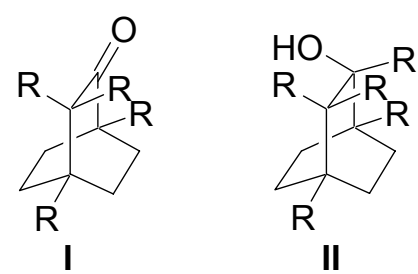

II

Some compounds of type I and II display olfactory properties similar to those of $\mathbf{1}{ }^{4}$ A general requisite for patchouli alcohol-like olfactory properties is a $13-15 \mathrm{C}$-atoms skeleton. ${ }^{5} \mathrm{In}$ the case of analogues of type II, another requisite is that the "hydroxyl group should be sterically shielded by a methyl or another group to a large extent but not completely". 6

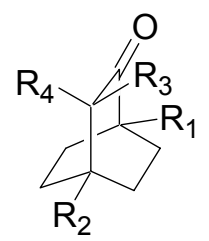

$2 \mathrm{R}_{1}=\mathrm{H}, \quad \mathrm{R}_{2}=\mathrm{H}, \quad \mathrm{R}_{3}=\mathrm{H}, \quad \mathrm{R}_{4}=\mathrm{H}$

$3 \mathrm{R}_{1}=\mathrm{Me}, \mathrm{R}_{2}=\mathrm{Me}, \mathrm{R}_{3}=\mathrm{H}, \quad \mathrm{R}_{4}=\mathrm{H}$

$4 \mathrm{R}_{1}=\mathrm{Me}, \mathrm{R}_{2}=i-\mathrm{Pr}, \mathrm{R}_{3}=\mathrm{H}, \quad \mathrm{R}_{4}=\mathrm{H}$

$5 \mathrm{R}_{1}=\mathrm{Me}, \quad \mathrm{R}_{2}=\mathrm{H}, \quad \mathrm{R}_{3}=\mathrm{Me}, \quad \mathrm{R}_{4}=\mathrm{Me}$

$8 \mathrm{R}_{1}=i-\mathrm{Pr}, \mathrm{R}_{2}=\mathrm{H}, \quad \mathrm{R}_{3}=\mathrm{H}, \quad \mathrm{R}_{4}=\mathrm{H}$

$9 \mathrm{R}_{1}=i-\mathrm{Pr}, \mathrm{R}_{2}=\mathrm{H}, \quad \mathrm{R}_{3}=\mathrm{Me}, \quad \mathrm{R}_{4}=\mathrm{Me}$

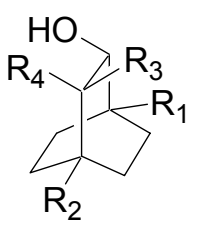

$6 \quad \mathrm{R}_{1}=\mathrm{H}, \quad \mathrm{R}_{2}=\mathrm{H}, \quad \mathrm{R}_{3}=\mathrm{Me}, \mathrm{R}_{4}=\mathrm{Me}$

$7 \mathrm{R}_{1}=\mathrm{Me}, \mathrm{R}_{2}=\mathrm{Me}, \mathrm{R}_{3}=\mathrm{Me}, \mathrm{R}_{4}=\mathrm{Me}$

$10 \mathrm{R}_{1}=i-\mathrm{Pr}, \mathrm{R}_{2}=\mathrm{H}, \quad \mathrm{R}_{3}=\mathrm{Me}, \mathrm{R}_{4}=\mathrm{Me}$

$11 \mathrm{R}_{1}=i-\mathrm{Pr}, \quad \mathrm{R}_{2}=\mathrm{H}, \quad \mathrm{R}_{3}=\mathrm{H}, \quad \mathrm{R}_{4}=\mathrm{H}$ 


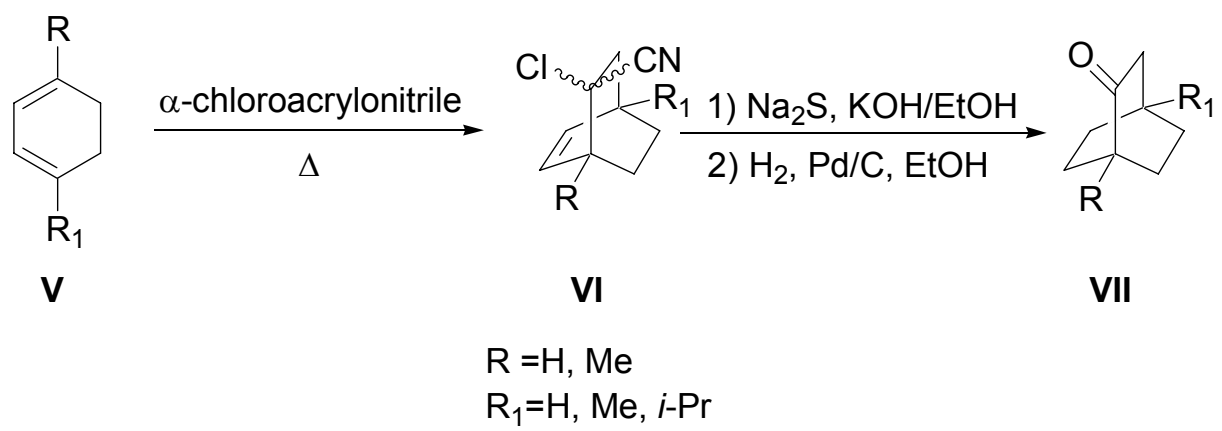

\section{Scheme 2}

Steric, regiochemical and electronic restrictions of the Diels-Alder reaction as well as the availability of suitable dienes limit the versatility of this approach and the number of analogues I and II of patchouli alcohol obtainable.

In our studies for the synthesis of natural products containing bicyclo[2.2.2] or via intermediates of this type, ${ }^{7}$ we have developed a synthetic approach to patchouli alcohol analogues, complementary to those so far adopted, ${ }^{3,4}$ and based on the Nagata 3sulfonyloxyethylcyclohexanone cyclization ${ }^{8}$ and the Sakurai cyclohex-2-en-1-one conjugate addition $^{9}$ (Scheme 3).

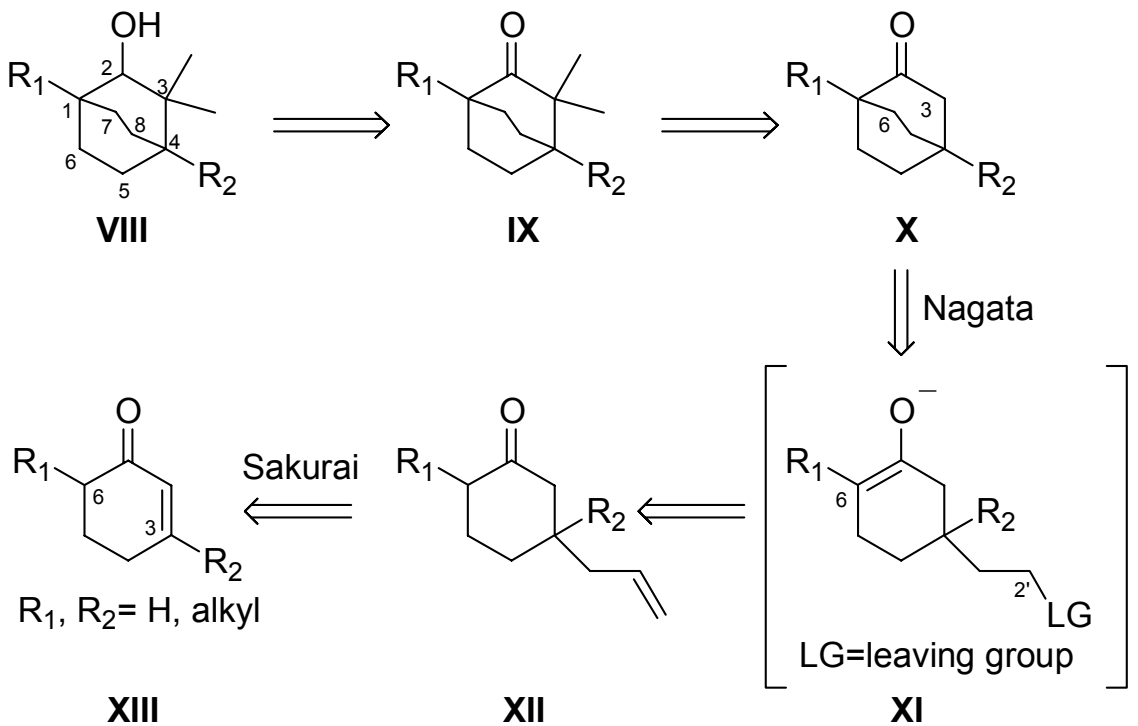

\section{Scheme 3}

The targets we selected were the known $\mathbf{2}^{4}, \mathbf{3}^{4}, \quad \mathbf{2 0}^{10}$ and the novel 1isopropylbicyclo[2.2.2] octan-2-one 8. Compound $\mathbf{8}$ was selected since its $\mathrm{C}(4)$ homologue $\mathbf{4}$ could be obtained only in trace amounts by the Diels-Alder approach, owing to the "strong steric influence of the bulky isopropyl group". ${ }^{4}$ In addition 1-isopropylbicyclo[2.2.2] octan-2-one 8 can 
be transformed into 9, a new analogue of type I, and into $\mathbf{1 0}$ and $\mathbf{1 1}$, new analogues of type II. Thus information on the effect of a bulky alkyl group at $\mathrm{C}(1)$ on the olfactory properties of analogues of type I and II could be obtained.

\section{Results and Discussion}

The starting materials for this study (Scheme 4) were commercially available anisoles $\mathbf{1 2}$ which were converted into $\alpha, \beta$-unsaturated ketones $\mathbf{1 3}$ by Birch reduction followed by acidic hydrolysis.

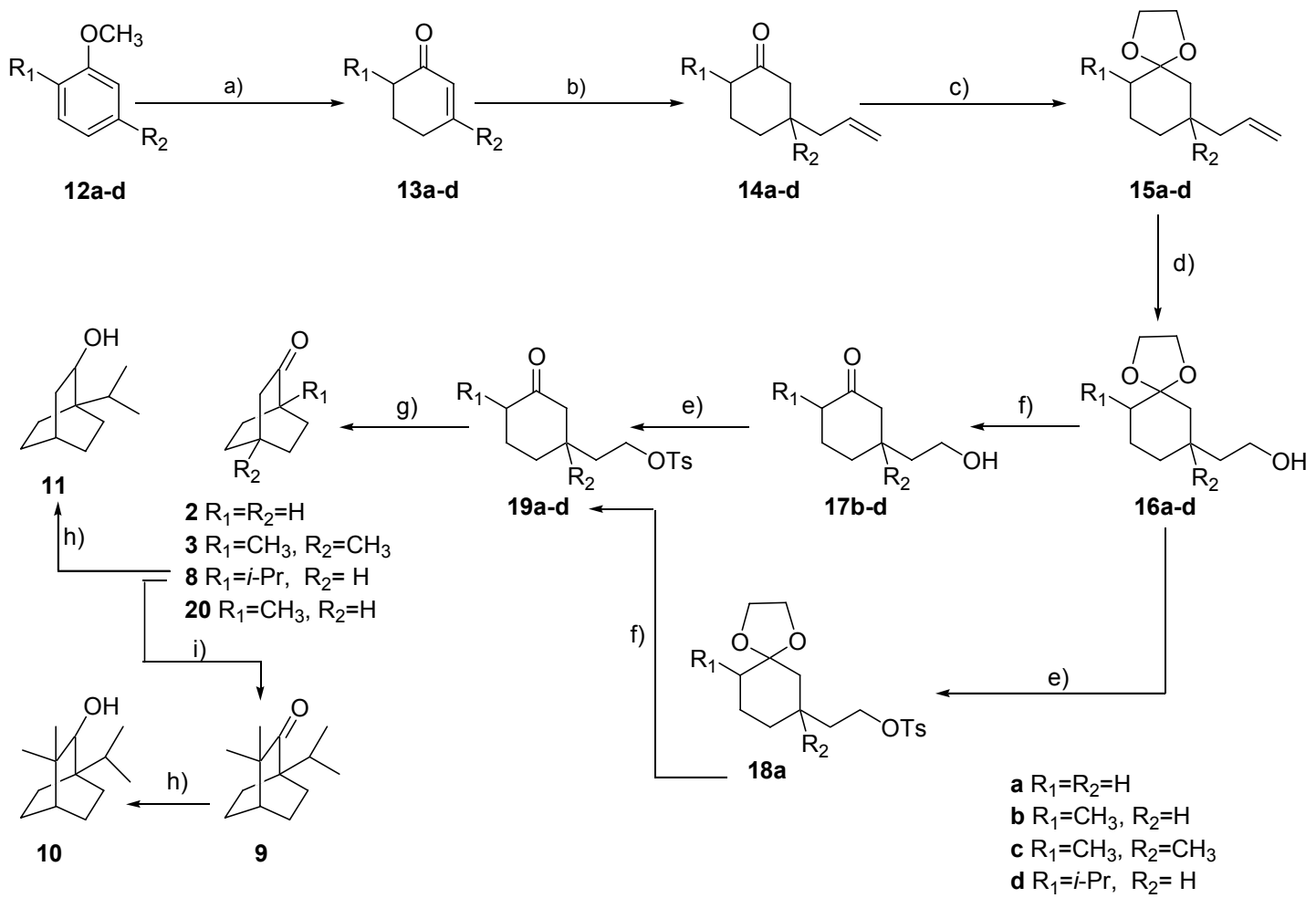

a) i) $\mathrm{Li}, \mathrm{NH}_{3}, t-\mathrm{BuOH}, \mathrm{THF},-50^{\circ} \mathrm{C}$; ii) $\mathrm{HCl}$; b) $\mathrm{TiCl}_{4}, \mathrm{CH}_{2} \mathrm{Cl}_{2}, \mathrm{Me}_{3} \mathrm{SiCH}_{2} \mathrm{CH}=\mathrm{CH}_{2},-78^{\circ} \mathrm{C}, \mathrm{Ar}$; c) $\mathrm{HO}\left(\mathrm{CH}_{2}\right)_{2} \mathrm{OH}$, benzene, $\mathrm{TsOH}$, reflux; d) i) $\mathrm{O}_{3}, \mathrm{CH}_{2} \mathrm{Cl}_{2},-78^{\circ} \mathrm{C}$; ii) $\mathrm{NaBH}_{4}$, $\mathrm{MeOH}$, r.t.; e) TsCl, Py, r.t.; f) THF/1N HCl 4/1, r.t.; g) $t$-BuOH/t-BuOK, $0^{\circ} \mathrm{C}$; h) $\mathrm{LiAlH}_{4}$, THF, r.t.; i) $\mathrm{CH}_{3}$ l, NaH, THF, reflux.

\section{Scheme 4}

The latter were allowed to react according to Sakurai ${ }^{9}$ with allyltrimethylsilane in the presence of $\mathrm{TiCl}_{4}$ to give 14. Protection of the carbonyl function of $\mathbf{1 4}$ as ethylene glycol acetal gave then 15. The side chain double bond was cleaved with $\mathrm{O}_{3} / \mathrm{NaBH}_{4}$ to give 16 , which on treatment with $1 \mathrm{~N} \mathrm{HCl} / \mathrm{THF}$ gave 17 . The latter were converted into tosylates 19 . In the case of 16a the transformation into 19a was also achieved by tosylation of $16 \mathbf{a}$ to $18 \mathbf{a}$, which was then 
deprotected giving 19a. Exposure of tosylates 19 to $t$-BuOK in $t$-BuOH gave 2, 3, 8 and 20. Previously ${ }^{1}$ compound 3 had been obtained from 15c as reported in Scheme 5.

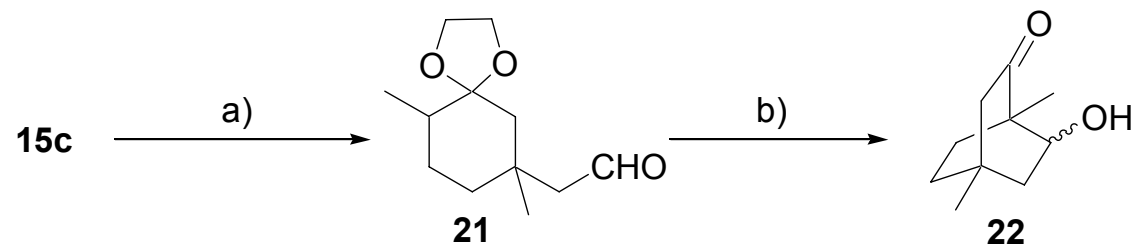

21

c)

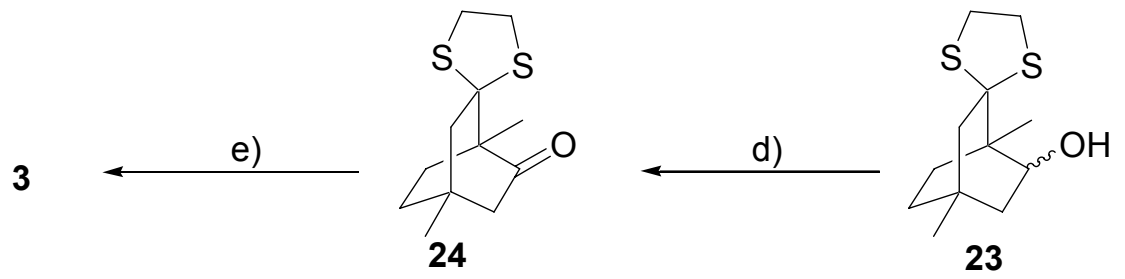

a) $\mathrm{OsO}_{4}, \mathrm{NaIO}_{4}$, THF, $\mathrm{H}_{2} \mathrm{O}$, r.t.; b) $\mathrm{THF} / 2 \mathrm{~N} \mathrm{HCl} \mathrm{3:1,} \mathrm{reflux;} \mathrm{c)} \mathrm{HSCH}_{2} \mathrm{CH}_{2} \mathrm{SH}$, $\mathrm{BF}_{3}-\mathrm{Et}_{2} \mathrm{O}$, r.t.; d) $\mathrm{PDC}, \mathrm{CH}_{2} \mathrm{Cl}_{2}$, r.t.; e) Raney-Nickel, $\mathrm{EtOH}$, reflux.

\section{Scheme 5}

Compound 8 was also converted with $\mathrm{MeI}$ and $\mathrm{NaH}$ into the highly volatile gemdimethylated compound 9 which could not be isolated. It was therefore reduced with $\mathrm{LiAlH}_{4}$ to 10. $\mathrm{LiAlH}_{4}$ reduction of $\mathbf{8}$ gave then $\mathbf{1 1}$.

\section{Evaluation of olfactory properties.}

The evaluation of olfactory properties requires a rather large amount of material. Thus only compounds $\mathbf{8}$ (type I) and $\mathbf{1 0}$ (type II) were subjected to olfactory evaluation.

Evaluation of analogue $\mathbf{8}$ revealed a scent reminiscent of eucalyptol and camphor, with the earthy-fruity part of patchouli oil. Thus the presence of the isopropyl group at C(1) appears to be sufficient for maintaining the earthy-fruity note of patchouli fragrance. In contrast, previously prepared analogues of type I having such olfactory properties were substituted at $\mathrm{C}(1), \mathrm{C}(3)$ and $\mathrm{C}(4){ }^{4}$

The $13 \mathrm{C}$ skeleton analogue $\mathbf{1 0}$ gave an earthy, mouldy and harsh odour with a technical and solvent-like note in olfactory evaluation. The HO-C(2) shielding by the isopropyl group at $\mathrm{C}(1)$ and by the two methyl groups at $\mathrm{C}(3)$ seems therefore to be responsible for the lack of the patchouli alcohol note in $\mathbf{1 0}$ (see prerequisites noted in the Introduction). 


\section{Conclusions}

In conclusion, by preparing known analogues $\mathbf{2 , 3}$ and 20 and new analogues 8-11, we have shown that the approach based on the Sakurai cyclohex-2-en-1-one conjugate addition and on the Nagata 3-sulfonyloxyethylcyclohexanone cyclization is quite convenient for the preparation of patchouli alcohol analogues of type I and II. Thus optically active patchouli alcohol analogues of type II can be prepared by performing the last reductive step with an asymmetric reducing reagent.

This approach could be useful for preparing a number of compounds of type I and II and in evaluating the influence on the olfactory properties of $\mathrm{C}(1)$-substituents different than $\mathrm{H}$ and methyl, thus contributing to the knowledge of structure/odour relationships in this class of compounds, a target which deserves considerable attention and efforts. ${ }^{11}$

\section{Acknowledgements}

We are grateful to Dr. Philip Kraft and Mr. Jean-Jacques Rouge, Givaudan Schweiz AG, Fragrance Research (Ueberlandstrasse $138 \mathrm{CH}-8600$ Duebendorf, Switzerland) for evaluating the olfactory properties of compounds $\mathbf{8}$ and $\mathbf{1 0 .}$

We are also grateful to Prof. John A. Findlay (University of New Brunswick, Fredericton N. B., Canada) for kindly revising the manuscript.

Financial support by Università degli Studi di Roma "La Sapienza" (Ateneo 60\%) and Ministero dell'Istruzione, Università e Ricerca (COFIN 2000 "Sintesi di Sostanze di Comunicazione Chirali" and COFIN 2002 "Aromi e Fragranze") is finally gratefully acknowledged.

\section{Experimental Section}

General Procedure: All solvents were anal. grade. TLC: Merck silica gel $60 \mathrm{~F}_{254}$. Column Chromatography (CC): silica gel 60, 70-230 mesh ASTM. IR Spectra: Shimadzu-470 scanning infrared spectrophotometer; in $\mathrm{cm}^{-1} .{ }^{1} \mathrm{H}-$ and ${ }^{13} \mathrm{C}$ NMR: Varian-Gemini-200, at 200 and $50 \mathrm{MHz}$ respectively; chemical shifts are on the $\delta$ scale and were referenced to residual $\mathrm{CDCl}_{3}$ (at 7.26 for ${ }^{1} \mathrm{H}$ and the center line of the triplet at 77.0 for ${ }^{13} \mathrm{C}$ NMR); $\delta$ in ppm; $J$ in $\mathrm{Hz}$. Compounds 12 and 13a are commercially available; compounds $2,{ }^{4,12} \mathbf{3},{ }^{4,13} \mathbf{1 3 b},{ }^{14} \mathbf{1 3 c},{ }^{15} \mathbf{1 3 d},{ }^{16} \mathbf{1 4 a},{ }^{9,17} \mathbf{1 4 b},{ }^{18}$ $\mathbf{1 5 a},{ }^{19} \mathbf{1 6},{ }^{20} \mathbf{1 7 b},{ }^{21} \mathbf{1 7 d},{ }^{22} \mathbf{1 8 a},{ }^{20 \mathrm{a}, 23} \mathbf{1 9 a},{ }^{8 \mathrm{~b}} \mathbf{2 0},{ }^{10}$ were already described in the literature. The ${ }^{13} \mathrm{C}-$ NMR spectra of compounds obtained as not easily separable diastereoisomeric mixtures (14c, 15c, 15d, 16c, 16d, 19b, 19c, 19d) are not reported. Olfactory properties of compounds 8 and 10 were evaluated at Givaudan Schweiz AG in a 10\% dipropylene glycol (DPG) solution. 
5-Allyl-2,5-dimethylcyclohexanone (14c). To a solution of enone 13c $(7.9 \mathrm{~g}, 63 \mathrm{mmol})$ in anhydrous $\mathrm{CH}_{2} \mathrm{Cl}_{2}(40 \mathrm{~mL})$, cooled to $-78^{\circ} \mathrm{C}$, a solution of $\mathrm{TiCl}_{4}(6.8 \mathrm{~mL}, 63 \mathrm{mmol})$ in anhydrous $\mathrm{CH}_{2} \mathrm{Cl}_{2}(13 \mathrm{~mL})$ was added dropwise. To the well stirred mixture a solution of allyltrimethylsilane $(11 \mathrm{~mL}, 69 \mathrm{mmol})$ in anhydrous $\mathrm{CH}_{2} \mathrm{Cl}_{2}(60 \mathrm{~mL})$ was added dropwise. After $1 \mathrm{~h}$ the mixture was allowed to warm slowly to $-30^{\circ} \mathrm{C}$ and stirred for $45 \mathrm{~min}$. The reaction was then quenched at $0^{\circ} \mathrm{C}$ with $\mathrm{H}_{2} \mathrm{O}$ and the whole poured into a separatory funnel. The layers were separated, the aqueous was extracted with $\mathrm{CH}_{2} \mathrm{Cl}_{2}(2 \times 50 \mathrm{~mL})$. The combined organic layers were repeatedly washed with sat. $\mathrm{NaHCO}_{3}$ solution, brine, dried with anhydrous $\mathrm{Na}_{2} \mathrm{SO}_{4}$ and concentrated at atmospheric pressure distilling off the solvent through a Vigreux column. The crude product was then purified by $\mathrm{CC}\left(\mathrm{SiO}_{2}\right.$ : petroleum ether $\left.\left(40-70^{\circ}\right) / \mathrm{Et}_{2} \mathrm{O}: 8.5 / 1.5\right)$ to afford 14c as an oil (7.8 g, $50 \mathrm{mmol}, 75 \%)$. Data of 14c: IR $\left(\mathrm{CCl}_{4}\right)$ : $1711\left(\mathrm{v}_{\mathrm{C}=\mathrm{O}}\right)$; ${ }^{1} \mathrm{H}-\mathrm{NMR}\left(\mathrm{CDCl}_{3}\right)$ : 5.86-5.58 (m, 1H), 5.07-4.91 ( $m, 2 \mathrm{H}), 2.34-1.34(m, 9 \mathrm{H}), 1.01-0.78(m, 6 \mathrm{H})$. $\mathrm{C}_{11} \mathrm{H}_{18} \mathrm{O}$ (166.26); Calc. C: 79.46; H: 10.91\%. Found C: 79.28; H: 11.18\%.

5-Allyl-2-isopropylcyclohexanone (14d). Compound 14d was prepared from known $13 d(2.7 \mathrm{~g}$, $20 \mathrm{mmol})$ as described for $14 \mathrm{c}$ from 13c. The crude product was then purified by $\mathrm{CC}\left(\mathrm{SiO}_{2}\right.$ : petroleum ether $\left.\left(40-70^{\circ}\right) / \mathrm{Et}_{2} \mathrm{O}: 8.5 / 1.5\right)$ to afford two oily diastereomers. Data of $\mathbf{1 4 d} \mathbf{d}_{R \mathrm{f}<}(0.9 \mathrm{~g}, 5$ mmol, 25\%): IR $\left(\mathrm{CCl}_{4}\right): 1711\left(\mathrm{v}_{\mathrm{C}=\mathrm{O}}\right)$; ${ }^{1} \mathrm{H}-\mathrm{NMR}\left(\mathrm{CDCl}_{3}\right): 5.84-5.58(\mathrm{~m}, 1 \mathrm{H}), 5.08-4.91(\mathrm{~m}, 2 \mathrm{H})$, 2.35-1.17 $(m, 11 \mathrm{H}), 0.92-0.73(\mathrm{~m}, 6 \mathrm{H}) ;{ }^{13} \mathrm{C}-\mathrm{NMR}\left(\mathrm{CDCl}_{3}\right): 214.0,135.8,116.6,57.3,45.7,40.1$, 38.9, 27.0, 26.9, 26.7, 20.8, 19.8. $\mathrm{C}_{12} \mathrm{H}_{20} \mathrm{O}$ (180.29); Calc. C: 79.94; H: $11.18 \%$. Found C: 79.70; H: $11.35 \%$. Data of $\mathbf{1 4 d}_{R \mathrm{f}}(0.9 \mathrm{~g}, 5 \mathrm{mmol}, 25 \%)$ : IR $\left(\mathrm{CCl}_{4}\right): 1710\left(\mathrm{v}_{\mathrm{C}=\mathrm{O}}\right) ;{ }^{1} \mathrm{H}-\mathrm{NMR}$ $\left(\mathrm{CDCl}_{3}\right): 5.81-5.55(\mathrm{~m}, 1 \mathrm{H}), 5.03-4.90(\mathrm{~m}, 2 \mathrm{H}), 2.43-1.20(\mathrm{~m}, 11 \mathrm{H}), 0.94-0.78(\mathrm{~m}, 6 \mathrm{H}) ;{ }^{13} \mathrm{C}-$ NMR $\left(\mathrm{CDCl}_{3}\right): 211.9,135.6,116.5,56.1,48.4,41.0,39.9,31.3,27.6,25.8,21.0,18.6 . \mathrm{C}_{12} \mathrm{H}_{20} \mathrm{O}$ (180.29); Calc. C: 79.94; H: $11.18 \%$. Found C: 79.75; H: $11.50 \%$.

9-Allyl-6,9-dimethyl-1,4-dioxaspiro[4.5]decane (15c). To a solution of ketone $14 \mathrm{c}$ (7.8 g, 50 $\mathrm{mmol})$ in anhydrous benzene $(50 \mathrm{~mL})$ an excess of ethylene glycol $(0.3 \mathrm{~mol})$ and a catalytic amount of $\mathrm{TsOH}$ were added. The mixture was refluxed under Ar with azeotropic removal of $\mathrm{H}_{2} \mathrm{O}$ (Dean-Stark trap), until the TLC (petroleum ether $\left(40-70^{\circ} \mathrm{C}\right) / \mathrm{Et}_{2} \mathrm{O}: 8.5 / 1.5$, $\left.R_{\mathrm{f}}(14 \mathrm{c})<R_{\mathrm{f}}(15 \mathrm{c})\right)$ indicated the complete disappearance of the starting material. The reaction mixture was then cooled to r.t., diluted with $\mathrm{Et}_{2} \mathrm{O}$, and washed with sat. $\mathrm{NaHCO}_{3}$ solution till neutral, brine, dried with anhydrous $\mathrm{Na}_{2} \mathrm{SO}_{4}$ and concentrated at atmospheric pressure distilling off the solvent through a Vigreux column. The crude product was then purified by $\mathrm{CC}\left(\mathrm{SiO}_{2}\right.$ : petroleum ether $\left.\left(40-70^{\circ}\right) / \mathrm{Et}_{2} \mathrm{O}: 9 / 1\right)$ affording $15 \mathrm{c}$ as an oil $(7.7 \mathrm{~g}, 36 \mathrm{mmol}, 73 \%)$. Data of 15c: ${ }^{1} \mathrm{H}-\mathrm{NMR}\left(\mathrm{CDCl}_{3}\right):$ 5.90-5.67 $(m, 1 \mathrm{H}), 5.04-4.92(m, 2 \mathrm{H}), 3.97-3.80(m, 4 \mathrm{H}), 2.31-1.10(m, 9 \mathrm{H})$, 0.97-0.81 (m, 6H). $\mathrm{C}_{13} \mathrm{H}_{22} \mathrm{O}_{2}(210.31)$; Calc. C: 74.24; H: 10.54\%. Found C: 74.03; H: 10.89\%.

9-Allyl-6-isopropyl-1,4-dioxaspiro[4.5]decane (15d). Compound 15d was prepared from 14d $(1.8 \mathrm{~g}, 10 \mathrm{mmol})$, as described for $15 \mathrm{c}$ from $14 \mathrm{c}$. The crude product was then purified by $\mathrm{CC}$ $\left(\mathrm{SiO}_{2}\right.$ : petroleum ether $\left.\left(40-70^{\circ}\right) / \mathrm{Et}_{2} \mathrm{O}: 9 / 1\right)$ affording $15 \mathrm{~d}$ as an oil (1.9 g, $\left.8.5 \mathrm{mmol}, 85 \%\right)$. Data of 15d: ${ }^{1} \mathrm{H}-\mathrm{NMR}\left(\mathrm{CDCl}_{3}\right)$ : 5.88-5.64 (m, $\left.1 \mathrm{H}\right)$, 5.08-4.90 $(m, 2 \mathrm{H}), 4.08-3.77(m, 4 \mathrm{H}), 2.20-1.19$ $(m, 11 \mathrm{H}), 0.95-0.81(m, 6 \mathrm{H})$.

$\mathrm{C}_{14} \mathrm{H}_{24} \mathrm{O}_{2}$ (224.34); Calc. C: 74.95; H: 10.78\%. Found C: 75.18; H: 11.13\%. 
2-(10-Methyl-1,4-dioxaspiro[4.5]dec-7-yl)-ethanol (16b). Compound 15b (5.5 g, $28 \mathrm{mmol})$ was dissolved in $\mathrm{CH}_{2} \mathrm{Cl}_{2}(20 \mathrm{~mL})$ and cooled to $-78^{\circ} \mathrm{C}$; a stream of $\mathrm{O}_{3}$ was then slowly passed through the solution until a faint blue color persisted. $\mathrm{NaBH}_{4}(2 \mathrm{~g}, 54 \mathrm{mmol})$ was then added portionwise, and the mixture stirred for $4 \mathrm{~h}$ at $-78^{\circ} \mathrm{C}$. After evaporation of the solvent under reduced pressure, the residue was taken up with water, neutralized with $5 \% \mathrm{HCl}$ solution and extracted with $\mathrm{CH}_{2} \mathrm{Cl}_{2}$. Combined extracts were washed with water, brine, dried with anhydrous $\mathrm{Na}_{2} \mathrm{SO}_{4}$ and evaporated under reduced pressure. The crude product was then purified by $\mathrm{CC}$ $\left(\mathrm{SiO}_{2}\right.$ : petroleum ether $\left.\left(40-70^{\circ}\right) / \mathrm{Et}_{2} \mathrm{O}: 6 / 4\right)$ to afford two oily diastereomers. Data of $\mathbf{1 6} \mathbf{b}_{R \mathrm{f}}(0.8$ g, $4.2 \mathrm{mmol}, 15 \%)$ : IR $\left(\mathrm{CCl}_{4}\right): 3635\left(\mathrm{v}_{\mathrm{OH}}\right) ;{ }^{1} \mathrm{H}-\mathrm{NMR}\left(\mathrm{CDCl}_{3}\right): 3.97-3.86(\mathrm{~m}, 4 \mathrm{H}), 3.73-3.52(\mathrm{~m}$, 2H), 2.08-1.07 $(m, 11 \mathrm{H}), 0.89(d, J=6.04,3 \mathrm{H}) ;{ }^{13} \mathrm{C}-\mathrm{NMR}\left(\mathrm{CDCl}_{3}\right): 110.8,64.9,64.7,60.9,44.5$, 38.3, 36.7, 34.8, 31.1, 22.7, 10.7. $\mathrm{C}_{11} \mathrm{H}_{20} \mathrm{O}_{3}$ (200.27); Calc. C: 65.97; H: 10.07\%. Found C: 65.85; H: 10.34\%. Data of $1 \mathbf{1 6 b}_{R \mathrm{f}<}(3.4 \mathrm{~g}, 17 \mathrm{mmol}, 60 \%)$ : IR $\left(\mathrm{CCl}_{4}\right): 3642\left(\mathrm{v}_{\mathrm{OH}}\right) ;{ }^{1} \mathrm{H}-\mathrm{NMR}$ $\left(\mathrm{CDCl}_{3}\right): 3.98-3.82(m, 4 \mathrm{H}), 3.73(t, J=6.87,2 \mathrm{H}), 2.09(s, 1 \mathrm{H}), 1.85-0.87(m, 10 \mathrm{H}), 0.83(d$, $J=6.41,3 \mathrm{H}) ;{ }^{13} \mathrm{C}-\mathrm{NMR}\left(\mathrm{CDCl}_{3}\right): 110.6,65.2,64.8,60.5,42.1,39.7,39.6,32.3,32.1,31.8,13.8$. $\mathrm{C}_{11} \mathrm{H}_{20} \mathrm{O}_{3}$ (200.27); Calc. C: 65.97; H: 10.07\%. Found C: 65.78; H: 10.42\%.

2-(7,10-Dimethyl-1,4-dioxaspiro[4.5]dec-7-yl)-ethanol (16c). Compound 16c was prepared from $15 \mathbf{c}(7.7 \mathrm{~g}, 36 \mathrm{mmol})$, as described for $\mathbf{1 6 b}$ from $\mathbf{1 5 b}$. The crude product was then purified by $\mathrm{CC}\left(\mathrm{SiO}_{2}\right.$ : petroleum ether $\left.\left(40-70^{\circ}\right) / \mathrm{Et}_{2} \mathrm{O}: 6 / 4\right)$ to afford $16 \mathrm{c}$ as an oil $(5.4 \mathrm{~g}, 25 \mathrm{mmol}, 70 \%)$. Data of 16c: IR $\left(\mathrm{CCl}_{4}\right)$ : $3475\left(\mathrm{v}_{\mathrm{OH}}\right) ;{ }^{1} \mathrm{H}-\mathrm{NMR}\left(\mathrm{CDCl}_{3}\right)$ : 3.96-3.75 (m, 4H), 3.67-3.54 (m, 2H), $2.16(s, 1 \mathrm{H}), 1.91-1.03(m, 9 \mathrm{H}), 0.96-0.79(m, 6 \mathrm{H})$.

$\mathrm{C}_{12} \mathrm{H}_{22} \mathrm{O}_{3}$ (214.30); Calc. C: 67.26; H: 10.35\%. Found C: 66.96; H: 10.72\%.

2-(10-Isopropyl-1,4-dioxaspiro[4.5]dec-7-yl)-ethanol (16d). Compound 16d was prepared from $15 \mathrm{~d}$ ( $1.9 \mathrm{~g}, 8.5 \mathrm{mmol})$, as described for $\mathbf{1 6 b}$ from $\mathbf{1 5 b}$. The crude product was then purified by $\mathrm{CC}\left(\mathrm{SiO}_{2}\right.$ : petroleum ether $\left.\left(40-70^{\circ}\right) / \mathrm{Et}_{2} \mathrm{O}: 6 / 4\right)$ to afford $\mathbf{1 6 d}$ as an oil $(1.5 \mathrm{~g}, 6.5 \mathrm{mmol}, 77 \%)$. Data of 16d: IR $\left(\mathrm{CCl}_{4}\right): 3422\left(\mathrm{v}_{\mathrm{OH}}\right) ;{ }^{1} \mathrm{H}-\mathrm{NMR}\left(\mathrm{CDCl}_{3}\right)$ : 4.03-3.84 (m, 4H), 3.68-3.60 (m, 2H), 2.17-0.96 (m, 12H), 0.92-0.79 ( $m, 6 \mathrm{H})$.

$\mathrm{C}_{13} \mathrm{H}_{24} \mathrm{O}_{3}(228.33)$; Calc. C: 68.38 ; H: 10.59\%. Found C: $68.22 ; \mathrm{H}: 10.81 \%$.

5-(2-Hydroxyethyl)-2,5-dimethylcyclohexanone (17c). A 4:1 THF/1N HCl solution (10 mL) of 16c (5.4 g, $25 \mathrm{mmol})$ was stirred at r.t. until TLC analysis $\left(\mathrm{SiO}_{2}\right.$; petroleum ether (40$\left.70^{\circ}\right) / \mathrm{Et}_{2} \mathrm{O}: 1 / 1 ; R_{\mathrm{f}}(\mathbf{1 6 c})>R_{\mathrm{f}}(\mathbf{1 7 c})$ ) showed the disappearance of the starting material (about $72 \mathrm{~h}$ ). The reaction mixture was neutralized with a sat. $\mathrm{NaHCO}_{3}$ solution and diluted with $\mathrm{Et}_{2} \mathrm{O}$; after separation, the aqueous phase was thoroughly extracted with $\mathrm{Et}_{2} \mathrm{O}$ and the combined organic extracts were washed with $\mathrm{H}_{2} \mathrm{O}$ and brine, dried with anhydrous $\mathrm{Na}_{2} \mathrm{SO}_{4}$ and evaporated under reduced pressure. The crude product was purified by $\mathrm{CC}\left(\mathrm{SiO}_{2}\right.$ : petroleum ether $\left(40-70^{\circ}\right) / \mathrm{Et}_{2} \mathrm{O}$ : $7 / 3)$ to afford two oily diastereomers. Data of $17 \mathbf{c}_{R f}<(1.5 \mathrm{~g}, 8.8 \mathrm{mmol}, 35 \%)$ : IR $\left(\mathrm{CCl}_{4}\right): 1715$ $\left(v_{\mathrm{C}=\mathrm{O}}\right) ;{ }^{1} \mathrm{H}-\mathrm{NMR}\left(\mathrm{CDCl}_{3}\right): 3.71(t, J=7.23,2 \mathrm{H}), 2.45-1.33(\mathrm{~m}, 10 \mathrm{H}), 1.08-0.77(\mathrm{~m}, 6 \mathrm{H}) ;{ }^{13} \mathrm{C}-$ NMR $\left(\mathrm{CDCl}_{3}\right): 213.0,58.7,53.3,46.7,44.5,38.8,36.6,31.3,23.1,14.3 . \mathrm{C}_{10} \mathrm{H}_{18} \mathrm{O}_{2}(170.25)$; Calc. C: 70.55 ; H: $10.66 \%$. Found C: 70.31; H: 10.90\%. Data of $17 \mathbf{c}_{R \mathrm{f}}(2.3 \mathrm{~g}, 14 \mathrm{mmol}, 55 \%)$ : IR $\left(\mathrm{CCl}_{4}\right): 1713\left(\mathrm{v}_{\mathrm{C}=\mathrm{O}}\right)$; ${ }^{1} \mathrm{H}-\mathrm{NMR}\left(\mathrm{CDCl}_{3}\right): 3.74-3.57(\mathrm{~m}, 2 \mathrm{H}), 2.45-1.37(\mathrm{~m}, 10 \mathrm{H}), 1.09-0.92(m$, 
$\left.{ }^{6 \mathrm{H}}\right) ;{ }^{13} \mathrm{C}-\mathrm{NMR}\left(\mathrm{CDCl}_{3}\right): 213.3,58.9,53.6,44.2,39.9,38.8,36.6,31.2,28.2,14.3 . \mathrm{C}_{10} \mathrm{H}_{18} \mathrm{O}_{2}$ (170.25); Calc. C: 70.55; H: 10.66\%. Found C: 70.24; H: $11.03 \%$.

2-(4-Methyl-3-oxocyclohexyl)ethyl-4-methylbenzenesulfonate (19b). To a stirred solution of 17b $(3.6 \mathrm{~g}, 23 \mathrm{mmol})$ in pyridine $(5 \mathrm{~mL}) \mathrm{TsCl}(4.4 \mathrm{~g}, 23 \mathrm{mmol})$ was added. After stirring for 18 $\mathrm{h}$ at r.t. $\mathrm{H}_{2} \mathrm{O}(5 \mathrm{ml})$ was added, followed, after additional $10 \mathrm{~min}$, by $\mathrm{Et}_{2} \mathrm{O}(20 \mathrm{~mL})$. The aqueous layer was separated and the organic one washed with $2 \mathrm{~N} \mathrm{HCl}, \mathrm{H}_{2} \mathrm{O}$, sat. $\mathrm{NaHCO}_{3}$ solution till neutral, brine, dried with anhydrous $\mathrm{Na}_{2} \mathrm{SO}_{4}$ and evaporated under reduced pressure. The crude product was then purified by $\mathrm{CC}\left(\mathrm{SiO}_{2}\right.$ : petroleum ether $\left.\left(40-70^{\circ}\right) / \mathrm{Et}_{2} \mathrm{O}: 6 / 4, R_{\mathrm{f}}(\mathbf{1 7 b})<R_{\mathrm{f}}(\mathbf{1 9 b})\right)$ to afford 19b as an oil $(6.8 \mathrm{~g}, 22 \mathrm{mmol}, 95 \%)$. Data of 19b: IR $\left(\mathrm{CCl}_{4}\right): 1715\left(v_{\mathrm{C}=\mathrm{O}}\right) ;{ }^{1} \mathrm{H}-\mathrm{NMR}$ $\left(\mathrm{CDCl}_{3}\right):$ 8.10-7.56 (m, 4H), 4.37-4.26 (m, 2H), $2.72(s, 3 \mathrm{H}), 2.66-1.42(\mathrm{~m}, 10 \mathrm{H}), 1.32-1.20(\mathrm{~m}$, $3 \mathrm{H})$.

$\mathrm{C}_{16} \mathrm{H}_{22} \mathrm{SO}_{4}$ (310.41); Calc. C: 61.91; H: 7.14; S: 10.33\%. Found C: 61.72; H: 7.39; S: 10.64\%. 2-(1,4-Methyl-3-oxocyclohexyl)ethyl-4-methylbenzenesulfonate (19c). Compound 19c was prepared from $17 \mathbf{c}(3.8 \mathrm{~g}, 22 \mathrm{mmol})$ as described for $\mathbf{1 9 b}$ from $\mathbf{1 7 b}$. The crude product was then purified by $\mathrm{CC}\left(\mathrm{SiO}_{2}\right.$ : petroleum ether $\left.\left(40-70^{\circ}\right) / \mathrm{Et}_{2} \mathrm{O}: 6 / 4\right)$ to afford $19 \mathrm{c}$ as an oil (5.2 $\mathrm{g}, 16$ mmol, 73\%). Data of 19c: IR $\left(\mathrm{CCl}_{4}\right)$ : $1713\left(v_{\mathrm{C}=0}\right)$; ${ }^{1} \mathrm{H}-\mathrm{NMR}\left(\mathrm{CDCl}_{3}\right): 8.09-7.58(m, 4 \mathrm{H}), 4.43-$ $4.32(m, 2 \mathrm{H}), 2.74(s, 3 \mathrm{H}), 2.65-1.53(m, 9 \mathrm{H}), 1.32-1.07(m, 6 \mathrm{H})$.

$\mathrm{C}_{17} \mathrm{H}_{24} \mathrm{SO}_{4}$ (324.44); Calc. C: 62.93; H: 7.46; S: 9.88\%. Found C: 63.23; H: 7.61; S: 10.11\%.

2-(4-Isopropyl-3-oxocyclohexyl)ethyl-4-methylbenzenesulfonate (19d). Compound 19d was prepared from $17 \mathbf{d}(2.1 \mathrm{~g}, 11 \mathrm{mmol})$ as described for $19 \mathbf{b}$ from $\mathbf{1 7 b}$. The crude product was purified by $\mathrm{CC}\left(\mathrm{SiO}_{2}\right.$ : petroleum ether $\left.\left(40-70^{\circ}\right) / \mathrm{Et}_{2} \mathrm{O}: 6 / 4\right)$ to afford $19 d$ as an oil $(3.3 \mathrm{~g}, 9.9$ mmol, 90\%). Data of 19d: IR $\left(\mathrm{CCl}_{4}\right): 1712\left(v_{\mathrm{C}=\mathrm{O}}\right) ;{ }^{1} \mathrm{H}-\mathrm{NMR}\left(\mathrm{CDCl}_{3}\right)$ : 7.78-7.32 $(\mathrm{m}, 4 \mathrm{H}), 4.06-$ $3.99(m, 2 \mathrm{H}), 2.43(s, 3 \mathrm{H}), 2.31-1.13(m, 11 \mathrm{H}), 1.00-0.76(m, 6 \mathrm{H})$.

$\mathrm{C}_{18} \mathrm{H}_{26} \mathrm{SO}_{4}$ (338.46); Calc. C: 63.87; H: 7.74; S: 9.47\%. Found C: 64.01; H: 8.07; S: $9.82 \%$.

1-Isopropylbicyclo[2.2.2] $\mathrm{mL}), t-\mathrm{BuO}^{-} \mathrm{K}^{+}(1.4 \mathrm{~g}, 12.5 \mathrm{mmol})$ was added. The mixture was stirred at r.t. until TLC (petroleum ether $\left.\left(40-70^{\circ}\right) / \mathrm{Et}_{2} \mathrm{O}: 1 / 1, R_{\mathrm{f}}(\mathbf{1 9 d})<R_{\mathrm{f}}(\mathbf{8})\right)$ showed the complete disappearance of the starting material $(1 \mathrm{~h})$. After careful neutralization with $0.1 \mathrm{~N} \mathrm{HCl}, \mathrm{Et}_{2} \mathrm{O}(10 \mathrm{~mL})$ was added, the aqueous layer separated, extracted with $\mathrm{Et}_{2} \mathrm{O}$. The combined organic phases were washed with $\mathrm{H}_{2} \mathrm{O}$, brine, dried with anhydrous $\mathrm{Na}_{2} \mathrm{SO}_{4}$ and evaporated at atmospheric pressure. The crude product was purified by $\mathrm{CC}\left(\mathrm{SiO}_{2}\right.$ : petroleum ether $\left.\left(40-70^{\circ}\right) / \mathrm{Et}_{2} \mathrm{O}: 8 / 2, R_{\mathrm{f}}(\mathbf{1 9 d})<R_{\mathrm{f}}(\mathbf{8})\right)$ to afford 8 as an oil $(1.4 \mathrm{~g}, 8.6 \mathrm{mmol}, 87 \%)$. Data of 8: IR $\left(\mathrm{CCl}_{4}\right): 1715\left(v_{\mathrm{C}=\mathrm{O}}\right) ;{ }^{1} \mathrm{H}-\mathrm{NMR}\left(\mathrm{CDCl}_{3}\right): 2.20-$ $2.19(\mathrm{~m}, 2 \mathrm{H}), 2.10$ (ps, 1H), 2.01 (sept, $J=6.87,1 \mathrm{H}), 1.77-1.41(\mathrm{~m}, 8 \mathrm{H}), 0.80(\mathrm{~d}, J=6.87,6 \mathrm{H})$;

${ }^{13} \mathrm{C}-\mathrm{NMR}\left(\mathrm{CDCl}_{3}\right): 217.7,47.8,45.3,28.9,27.7,25.2,24.6,17.6$. $\mathrm{C}_{11} \mathrm{H}_{18} \mathrm{O}$ (166.26); Calc. C: 79.46; H: 10.91\%. Found C: 79.58; H: 11.12\%.

1-Isopropyl-3,3-dimethylbicyclo[2.2.2]octan-2-ol (10). To a stirred solution of 8 (380 mg, 2.3 $\mathrm{mmol})$ in THF $(3 \mathrm{~mL}) \mathrm{NaH}(0.8 \mathrm{~g}, 3.5 \mathrm{mmol})$ was added portionwise under Ar and the mixture was stirred at r.t. for $40 \mathrm{~min} . \mathrm{CH}_{3} \mathrm{I}(4 \mathrm{~mL}, 0.07 \mathrm{~mol})$ was then added dropwise and the mixture refluxed under Ar until TLC monitoring $\left(\mathrm{SiO}_{2}\right.$; petroleum ether $\left.\left(40-70^{\circ}\right) / \mathrm{Et}_{2} \mathrm{O}: 9 / 1, R_{\mathrm{f}}(\mathbf{8})<R_{\mathrm{f}}(\mathbf{9})\right)$ showed the disappearance of the starting material. The reaction mixture was neutralized with 
$0.5 \mathrm{~N} \mathrm{HCl}$, washed with $\mathrm{H}_{2} \mathrm{O}$, brine, dried with anhydrous $\mathrm{Na}_{2} \mathrm{SO}_{4}$ and evaporated at atmospheric pressure. The residue constituted by 1-isopropyl-3,3-dimethyl-bicyclo[2.2.2] octan-2-one (9) was used as such in the following step.

A solution of compound 9 in anhydrous THF $(10 \mathrm{~mL})$ was treated with $\mathrm{LiAlH}_{4}(130 \mathrm{mg}, 3.3$ mmol). The reaction mixture was stirred at r.t. until TLC analysis (petroleum ether (40$\left.\left.70^{\circ}\right) / \mathrm{Et}_{2} \mathrm{O}: 9 / 1, R_{\mathrm{f}}(\mathbf{1 0})<R_{\mathrm{f}}(\mathbf{9})\right)$ showed the disappearance of the starting material $(1 \mathrm{~h})$. Excess $\mathrm{LiAlH}_{4}$ was quenched by dropwise addition of $\mathrm{H}_{2} \mathrm{O}$ and neutralized with $0.1 \mathrm{~N} \mathrm{HCl}$. The layers were separated and the aqueous one extracted three times with $\mathrm{Et}_{2} \mathrm{O}$. The combined organic layers were washed with brine, dried with anhydrous $\mathrm{Na}_{2} \mathrm{SO}_{4}$ and concentrated at atmospheric pressure. The crude residue was purified by $\mathrm{CC}\left(\mathrm{SiO}_{2}\right.$; petroleum ether $\left.\left(40-70^{\circ}\right) / \mathrm{Et}_{2} \mathrm{O}: 9.5 / 0.5\right)$ to afford 10 as an oil (350 mg, $1.8 \mathrm{mmol}, 77 \%)$. Data of 10: IR $\left(\mathrm{CCl}_{4}\right)$ : $3516\left(\mathrm{v}_{\mathrm{OH}}\right) ;{ }^{1} \mathrm{H}-\mathrm{NMR}$ $\left(\mathrm{CDCl}_{3}\right): 3.36(s, 1 \mathrm{H}), 1.89-1.12(\mathrm{~m}, 11 \mathrm{H}), 1.01(s, 3 \mathrm{H}), 0.99(s, 3 \mathrm{H}), 0.81(d, J=6.85,3 \mathrm{H}), 0.76$ $(d, J=6.92,3 \mathrm{H}) ;{ }^{13} \mathrm{C}-\mathrm{NMR}\left(\mathrm{CDCl}_{3}\right): 78.0,38.6,36.4,36.3,30.8,30.0,23.2,22.9,22.2,21.9$, 21.6, 17.2, 16.9 .

$\mathrm{C}_{13} \mathrm{H}_{24} \mathrm{O}$ (196.33); Calc. C: 79.53; H: 12.32\%. Found C: 79.83; H: 12.56\%.

1-Isopropyl-bicyclo[2.2.2] octan-2-ol (11). To a solution of compound 8 (150 mg, $0.9 \mathrm{mmol})$ in anhydrous THF $(5 \mathrm{~mL}) \mathrm{LiAlH}_{4}(50 \mathrm{mg}, 1.3 \mathrm{mmol})$ was added. The reaction mixture was stirred at r.t. until TLC analysis $\left(\mathrm{SiO}_{2}\right.$ : petroleum ether $\left.\left(40-70^{\circ}\right) / \mathrm{Et}_{2} \mathrm{O}: 9 / 1, R_{\mathrm{f}}(\mathbf{8})>R_{\mathrm{f}}(\mathbf{1 1})\right)$ showed the disappearance of the starting material (1h). Excess $\mathrm{LiAlH}_{4}$ was quenched by dropwise addition of $\mathrm{H}_{2} \mathrm{O}$ and neutralized with $0.1 \mathrm{~N} \mathrm{HCl}$. The layers were separated, and the aqueous one extracted with $\mathrm{Et}_{2} \mathrm{O}$, washed with brine, dried with anhydrous $\mathrm{Na}_{2} \mathrm{SO}_{4}$ and concentrated at atmospheric pressure. The crude residue was purified by $\mathrm{CC}\left(\mathrm{SiO}_{2}\right.$; petroleum ether $\left.\left(40-70^{\circ}\right) / \mathrm{Et}_{2} \mathrm{O}: 9.5 / 0.5\right)$ to afford 11 as an oil (116 mg, $0.7 \mathrm{mmol}, 77 \%)$. Data of 11: IR $\left(\mathrm{CCl}_{4}\right): 3543\left(\mathrm{v}_{\mathrm{OH}}\right)$; ${ }^{1} \mathrm{H}-\mathrm{NMR}$ $\left(\mathrm{CDCl}_{3}\right): 3.91-3.85(\mathrm{~m}, 1 \mathrm{H}), 2.05-1.92(\mathrm{~m}, 1 \mathrm{H}), 1.71-1.03(\mathrm{~m}, 12 \mathrm{H}), 0.83(\mathrm{~d}, J=6.32,3 \mathrm{H}), 0.80$ $(d, J=6.68,3 \mathrm{H}) ;{ }^{13} \mathrm{C}-\mathrm{NMR}\left(\mathrm{CDCl}_{3}\right): 69.7,38.3,36.7,30.8,26.1,25.0,24.8,22.9,21.5,17.1$, 17.0 .

$\mathrm{C}_{11} \mathrm{H}_{20} \mathrm{O}$ (168.28); Calc. C: 78.51; H: 11.98\%. Found C: 78.68; H: $12.28 \%$.

\section{References}

1. La Bella, A. Ph.D. Thesis, University "La Sapienza”, Rome, 2006.

2. (a) Büchi, P.; MacLeod, W., Jr. J. Am. Chem. Soc. 1962, 84, 3205. (b) Büchi, G.; MacLeod, W. D., Jr.; Padilla, O. J. J. Am. Chem. Soc. 1964, 86, 4438. (c) Danishefsky, S.; Duman, D. Chem. Commun. 1968, 1287. (d) Mirrington, R. N.; Schmalzl, K. J. J. Org. Chem. 1972, 37, 2871. (e) Näf, F.; Ohloff, G. Helv. Chim. Acta 1974, 57, 1868. (f) Yamada, K.; Kyotani, Y.; Manabe, S.; Suzuki, M. Tetrahedron 1979, 35, 293. (g) Magee, T. V.; Stork, G.; Fludzinski, P. Tetrahedron Lett. 1995, 36, 7607. (h) Srikrishna, A; Satyanarayana, G. Tetrahedron: Asymmetry 2005, 16, 3992. 
3. (a) Spreitzer, H. Helv. Chim. Acta 1990, 73, 1730. (b) Spreitzer, H. Monat. Chem. 1992, 123, 587.

4. Weyerstahl, P.; Gansau, C.; Marschall H. Flavour Fragr. J. 1993, 8, 297.

5. Weyerstahl, P.; Splittgerber, H.-D.; Walteich, J.; Wollny, T. J. Ess. Oil Res. 1989, 1, 1.

6. Weyerstahl, P. J. Prakt. Chem. 1994, 336, 95.

7. a) De Santis, B.; Iamiceli, A.L.; Marini Bettolo, R.; Migneco, L.M.; Scarpelli, R.; Cerichelli, G.; Fabrizi, G.; Lamba, D. Helv. Chim. Acta 1998, 81, 2375 and references therein cited. (b) Migneco, L. M.; Leonelli, F.; Marini Bettolo, R. ARKIVOC 2004, 7, 253, and references therein cited.

8. (a) Nagata, W.; Sugasawa, T.; Narisada, M.; Wakabayashi, T.; Hayase, Y. J. Am. Chem. Soc. 1963, 85, 2342. (b) Etheredge, S. J. J. Org. Chem. 1966, 31, 1990. (c) Piers, E.; Britton, R. W.; De Waal, W. Chem. Commun. 1969, 1069.

9. Hosomi, A.; Sakurai, H. J. Am. Chem. Soc. 1977, 99, 1673.

10. (a) Yates, P.; Langford, G. E. Can. J. Chem. 1981, 59, 344. (b) Langford, G. E.; Auksi, H.; Gosbee, J. A.; MacLahlan, F. N.; Yates, P. Tetrahedron 1981, 37, 1091.

11. Kraft, P.; Weymuth, C.; Nussbaumer, C. Eur. J. Org. Chem. 2006, 1403.

12. (a) Diels, O.; Alder, K.; Petersen, E.; Querberitz, F. Ann. 1930, 478, 137. (b) Powers, D. C.; Leber, P. A.; Gallagher, S. S.; Higgs, A. T.; McCullough, L. A.; Baldwin, J. E. J. Org. Chem. 2007, 72, 187.

13. Jacquesy, J. C.; Jacquesy, R.; Patoiseau, J. F. Tetrahedron 1976, 32, 1699.

14. (a) Kotz, A.; Steinhorst, H. Ann. 1911, 379, 1. (b) Marques, F. A.; Lenz, C. A.; Simonelli, F.; Maia, B. H. L. N. S.; Vellasco, A. P.; Eberlin, M. N. J. Nat. Prod. 2004, 67, 1939.

15. (a) Kotz, A.; Blemdermann, K.; Manhert, F.; Rosenbusch, R. Ann. 1913, 400, 72. (b) Solladié-Cavallo, A.; Jierry, L.; Bouérat, L.; Taillasson, P. Tetrahedron: Asymmetry 2001, 12,883 .

16. (a) Stork, G.; White, W. N. J. Am. Chem. Soc. 1953, 75, 4119. (b) Paquette, L. A.; Doehner, R. F., Jr. J. Org. Chem. 1980, 45, 5105.

17. (a) Macrosson, W. D. K.; Martin, J.; Parker, W.; Penrose, A. B. J. Chem. Soc. Sect. C 1968, 18, 2323. (b) Yadav, J. S.; Reddy, B. V. S.; Sadasiv, K.; Satheesh, G. Tetrahedron Lett. 2002, 43, 9695.

18. (a) Mori, K.; Nagano, E. Biocatalysis 1990, 3, 25. (b) Yanagisawa, A.; Shigeki, H.; Katsutaka, Y.; Yamamoto, H. J. Am. Chem. Soc. 1994, 116, 6130.

19. Taber, D. F.; Saleh, S. A.; Korsmeyer, R. W. J. Org. Chem. 1980, 45, 4699.

20. (a) Stetter, H.; Krueger-Hansen, I.; Rizk, M. Chem. Ber. 1961, 94, 2702. (b) Schmoldt, P.; Mattay, J. Synthesis 2003, 7, 1071.

21. Felkin, H.; Lion, C. Tetrahedron 1971, 27, 1375.

22. Murphy, R.; Prager, R. H. J. Organometallic Chem. 1978, 156, 133.

23. Nakazaki, M.; Naemura, K.; Nakahara, S. Chem. Commun. 1979, $2,82$. 